University of Nebraska - Lincoln

DigitalCommons@University of Nebraska - Lincoln

\title{
Crop, Native Vegetation, and Biofuels: Response of White- Tailed Deer to Changing Management Priorities
}

\author{
W. David Walter \\ USDA-APHIS-Wildlife Services \\ Kurt C. Vercauteren \\ USDA-APHIS-Wildlife Services, kurt.c.vercauteren@usda.gov \\ Jason Gilsdorf \\ University of Nebraska-Lincoln \\ Scott E. Hygnstrom \\ University of Nebraska-Lincoln, shygnstrom1@unl.edu
}

Follow this and additional works at: https://digitalcommons.unl.edu/icwdm_usdanwrc

Part of the Environmental Sciences Commons

Walter, W. David; Vercauteren, Kurt C.; Gilsdorf, Jason; and Hygnstrom, Scott E., "Crop, Native Vegetation, and Biofuels: Response of White- Tailed Deer to Changing Management Priorities" (2009). USDA Wildlife Services - Staff Publications. 985.

https://digitalcommons.unl.edu/icwdm_usdanwrc/985

This Article is brought to you for free and open access by the U.S. Department of Agriculture: Animal and Plant Health Inspection Service at DigitalCommons@University of Nebraska - Lincoln. It has been accepted for inclusion in USDA Wildlife Services - Staff Publications by an authorized administrator of DigitalCommons@University of Nebraska - Lincoln. 


\title{
Crop, Native Vegetation, and Biofuels: Response of White- Tailed Deer to Changing Management Priorities
}

\author{
W. DAVID WALTER, ${ }^{1}$ United States Department of Agriculture, Animal and Plant Health Inspection Services, National Wildlife Research Center, 4101 \\ LaPorte Avenue, Fort Collins, CO 80521-2154, USA \\ KURT C. VERCAUTEREN, United States Department of Agriculture, Animal and Plant Health Inspection Services, National Wildlife Research Center, \\ 4101 LaPorte Avenue, Fort Collins, CO 80521-2154, USA \\ JASON M. GILSDORF, ${ }^{2}$ School of Natural Resources, 135 Hardin Hall, University of Nebraska, Lincoln, NE 68583-0974, USA \\ SCOTT E. HYGNSTROM, School of Natural Resources, 415 Hardin Hall, University of Nebraska, Lincoln, NE 68583-0974, USA
}

\begin{abstract}
The expansion of the cellulosic biofuels industry throughout the United States has broad-scale implications for wildlife management on public and private lands. Knowledge is limited on the effects of reverting agriculture to native grass, and vice versa, on size of home range and habitat use of white-tailed deer (Odocoileus virginianus). We followed 68 radiocollared female deer from 1991 through 2004 that were residents of DeSoto National Wildlife Refuge (DNWR) in eastern Nebraska, USA. The refuge was undergoing conversion of vegetation out of row-crop agriculture and into native grass, forest, and emergent aquatic vegetation. Habitat in DNWR consisted of $30 \%$ crop in 1991 but removing crops to establish native grass and wetland habitat at DNWR resulted in a 44\% reduction in crops by 2004. A decrease in the amount of crops on DNWR contributed to a decline in mean size of annual home range from 400 ha in 1991 to 200 ha in 2005 but percentage of crops in home ranges increased from $21 \%$ to $29 \%$. Mean overlap for individuals was $77 \%$ between consecutive annual home ranges across 8 years, regardless of crop availability. Conversion of crop to native habitat will not likely result in home range abandonment but may impact disease transmission by increasing rates of contact between deer social groups that occupy adjacent areas. Future research on condition indices or changes in population parameters (e.g., recruitment) could be incorporated into the study design to assess impacts of habitat conversion for biofuel production. (JOURNAL OF WILDLIFE MANAGEMENT 73(3):339-344; 2009)
\end{abstract}

DOI: $10.2193 / 2008-162$

KEY WORDS biofuels, Conservation Reserve Program, core area, crop, habitat use, home range, Odocoileus virginianus, radiotelemetry, white-tailed deer.

The United States is the second- and third-largest producer of ethanol and biodiesel, respectively, in the world and production of biofuel nearly doubled between 2000 and 2005 (World Resources Institute 2008). Furthermore, the promise of cellulosic ethanol to the biofuel industry will result in conversion of agricultural lands throughout the United States with little knowledge on the effects to wildlife (Bies 2006, Tilman et al. 2006). Information on the effects of habitat alteration on long-term use of landscapes by wildlife can improve management of wildlife on public and private lands. Long-term research ( $\geq 5 \mathrm{yr}$ ) on free-ranging white-tailed deer (Odocoileus virginianus) is limited (Dusek et al. 1989, Nixon et al. 1991, Nelson 1993, Nelson and Mech 1999), and even fewer studies focus on short-term movements, size of home ranges, and space use of deer in response to habitat or population management (Henderson et al. 2000, Kilpatrick et al. 2001). Long-term research enables managers to elucidate relationships between animals and their habitat on several temporal scales and can serve to enhance local deer management in response to changing habitat management priorities.

The relationship between density of a population and size of home range of deer is unclear and results of studies that have correlated habitat quality, density, and intraspecific competition have been inconsistent (Tierson et al. 1985,

\footnotetext{
${ }^{1}$ E-mail: W.David.Walter@aphis.usda.gov

2 Present address: United States Department of Agriculture/Animal and Plant Health Inspection Services/Wildlife Services, 9001 E Frontage Road, Suite A, Palmer, AK 99645, USA
}

Henderson et al. 2000, Kilpatrick et al. 2001, Lopez et al. 2005). In agro-forest ecosystems of the Midwest, riparian areas are used extensively by deer for cover and travel corridors and typically contain high-quality forage, free water, and vertical cover making them attractive feeding areas (Dusek et al. 1988, 1989; Nixon et al. 1991). Riparian and emergent aquatic vegetation (e.g., cattails [Typha spp.], phragmites [Phragmites australis]) are areas known to maintain regional populations of deer and may be the key to continued occupancy of intensively farmed areas in the Midwest (Nixon et al. 1991, Kernohan et al. 1996, Smith et al. 2007). In areas dominated by agriculture, permanent habitat with sufficient vertical structure may provide the only available protective cover for deer following the harvest of crops (VerCauteren and Hygnstrom 1998). Alterations of the landscape that affect thermal cover (i.e., forestry practices, Conservation Reserve Program [CRP]) could impact the ability of local areas to support populations of deer.

The Desoto National Wildlife Refuge (DNWR) is an agro-forest matrix situated in a forested riparian corridor, surrounded by agriculture, where density of deer increased during winter due to protective cover offered by forests and availability of agriculture (VerCauteren and Hygnstrom 1998). To reestablish native habitats to DNWR, about $4 \%$ of agricultural crops per year were converted to native grass, forest, and aquatic habitat beginning in 1990-1991. Gradual conversion from crops to native habitat prevented a pre- and postcomparison of size of home range used by deer but 
provided us with data on the influence an annual decrease in crops had on size of home range for numerous deer over a 15-year period. Our objectives were to determine the 1) fidelity of deer to their annual home ranges undergoing moderate landscape conversion, and 2) amount and percentage of habitat and crops in annual home ranges and core areas in response to a gradual reduction in crops planted over a 14-year period.

\section{STUDY AREA}

We conducted the study at DNWR from 1991 through 2004. The DNWR is located $30 \mathrm{~km}$ north of Omaha, Nebraska, USA, in the Missouri River valley of eastern Nebraska and western Iowa. The DNWR is a 3,385-ha mosaic of forest, agricultural crops, grass, and aquatic habitats. Deciduous forest, dominated by mature eastern cottonwood (Populus deltoides), composed 40\% (1,350 ha) of DNWR. Understory included rough-leafed dogwood (Cornus drummondii), hackberry (Celtis occidentalis), mulberry (Morus rubra), and green ash (Fraxinus pennsylvanica). Poison ivy (Rhus radicans) and common scouring-rush (Equisetum hyemale) dominated the ground layer. Crops such as corn, soybeans, grain sorghum, alfalfa, and a wheatclover mix were cultivated on a 3-year rotation. Sorghum, alfalfa, clover, and $10-16 \%$ of the corn were left standing through winter as food plots for wildlife. In 1991, 31\% (1,035 ha) of DNWR consisted of crops, but by 2004 only $17 \%$ (581 ha) consisted of agriculture. In 2004, native grasses comprised 21\% (700 ha) of DNWR and included big bluestem (Andropogon gerardii), little bluestem (Schizachyrium scoparium), indiangrass (Sorghastrum nutans), switchgrass (Panicum virgatum), and sideoats grama (Bouteloua curtipendula) that were planted to convert crops to native prairie habitat. Cool-season grasses (e.g., smooth brome [Bromus inermis], western wheatgrass [Agropyron smithii]) were incorporated to increase diversity of the grass habitat along with several wildflowers such as lead plant (Amorpha canescens), showy partridge pea (Cassia chamaecrista), and prairie wild rose (Rosa arkansana).

Landscape surrounding DNWR was predominately corn fields, which provided food and cover to deer only during the growing season and remained unchanged during our study (VerCauteren and Hygnstrom 1998). The DNWR was located along the Missouri River and acted as a refuge for deer during winter by providing forage and protective cover that was not available in surrounding landscape (VerCauteren and Hygnstrom 1998). From 1991 to 2001, 220 ha of agricultural crops were converted to wetland and native grass habitat resulting in about a $4 \%$ reduction in agricultural crops per year. In 2001, in accordance with the National Wildlife Refuge System Improvement Act of 1997, staff of DNWR prepared a Comprehensive Conservation Plan to specify a direction for management of the refuge (U.S. Fish and Wildlife Service 2001). The Comprehensive Conservation Plan proposed that $75 \%$ (610 ha) of remaining crops be reverted to native grass, forest, and aquatic habitat over the next 15 years.
We estimated that the density of deer at DNWR was 1925 deer $/ \mathrm{km}^{2}$ from 1991 to 1998 , based on pellet group counts, visual counts, and agency estimates (VerCauteren 1998) and 35-40 deer $/ \mathrm{km}^{2}$ from 2003 to 2004 , based on helicopter surveys. An inverse relationship between density of deer and weight (i.e., an index of condition) suggested that deer condition on DNWR was negatively affected by loss of crops and higher densities of deer (S. E. Hygnstrom, University of Nebraska, unpublished data).

\section{METHODS}

We captured 351 deer from January 1991 to June 2004. We marked all deer with colored and numbered ear tags, and we equipped 123 females with radiotransmitters (150-152 $\mathrm{MHz}$; Advanced Telemetry Systems Inc., Isanti, MN). We aged deer as juvenile ( $<1 \mathrm{yr}$ old $)$ or adult $(>1 \mathrm{yr}$ old $)$ when captured. Captured deer that we did not radiocollar included males $(n=144)$, young females that were too small to equip with radiocollars $(n=61)$, and recent recaptures $(n$ $=23$ ). We captured most deer during winter with nettedcage traps baited with corn (VerCauteren et al. 1999), but rocket-nets and chemical immobilization using transmitterequipped darts (Kilpatrick et al. 1996) to locate immobilized deer also accounted for some deer captures.

We included in our home range analyses 68 radiocollared female deer that had annual home ranges contained within DNWR (residents). We included in our habitat use analysis 63 radiocollared deer that were residents and had their entire home range within DNWR. We did not include the 5 resident deer with home ranges that extended off of DNWR in our habitat use analyses because of the lack of annual data on crop type available for those areas. Nineteen radiocollared deer died before we could collect sufficient data to estimate annual home ranges. The remaining 36 radiocollared deer emigrated $(n=18)$, migrated $(n=10)$, or had most of their home range extend off of DNWR $(n=8)$. All of our methods were approved by the University of Nebraska-Lincoln Institutional Animal Care and Use Committee (IACUC no. 99-03-014).

We determined locations of radiocollared deer using an integrated vehicle-mounted very high frequency telemetry system (Gilsdorf et al. 2008). Telemetry system tests from true and estimated bearings resulted in an average angular error of $2.63^{\circ} \pm 12.1(\mathrm{SD})$ and mean location error distance of $128 \mathrm{~m} \pm 91.3$ (SD; Gilsdorf et al. 2008). We collected locations randomly throughout a 24 -hour period to ensure locations of deer were not biased towards periods of activity or inactivity. Each location consisted of 2-4 directional azimuths taken from known receiver locations and we used Location of a Signal (Ecological Software Solutions, Sacramento, CA) to generate telemetry locations (Gilsdorf et al. 2008). We accepted locations that had error polygons $\leq 1$ ha. We established $29 \%(n=4,315)$ of locations of radiocollared deer by direct observation.

We imported deer locations into Geographic Information Systems software ArcView 3.2 and used an adaptive kernel method (Worton 1995, Rodgers and Carr 1998) to 
construct estimates of annual home ranges for each deer. We used $95 \%$ isopleths to delineate annual home ranges and $25 \%$ isopleths to delineate core areas with the unit variance style of standardization, h_ref smoothing factor automation (Worton 1995). We defined annual home ranges as beginning on 15 March and ending 14 March of the following year to coincide with phenological periods. We estimated annual home ranges using a mean of 78 locations $\pm 5.8(\mathrm{SE}$; range $=20-460)$ per deer. We found no relationship between sizes of home ranges and number of locations used to estimate them. Exact ages were known for $50 \%(n=34)$ of radiocollared deer; remaining deer $(n=34)$ were adults of unknown age. Yearling deer were $\geq 1$ year and $\leq 2$ years old and were those deer we captured as juveniles $(\leq 1 \mathrm{yr})$. We could not pool by age class (i.e., yearling, ad) for home ranges of deer because size of home ranges of yearling deer were larger than those of adult deer $\left(t_{84}=2.63\right.$, $P=0.010)$.

We characterized vegetation annually with maps provided by DNWR biologists using ArcMap 9.1, including forest, crop, grass, and bare ground. Type of crops planted on DNWR varied among years but included primarily corn, soybeans, and wheat-clover mix. Due to minimal representation ( $\leq 17 \%$ of crops) we pooled all remaining crops into other. About 17\% (560 ha) of DNWR consisted of the Missouri River and an associated oxbow lake and was insignificant as deer habitat. Therefore, we did not include aquatic habitat in our analyses. Bareground and facilities covered $<2 \%$ of the available area and were not significant vegetation types $\left(t_{452}=0.43, P=0.668 ; t_{452}=0.67, P=\right.$ 0.504 , respectively) so we pooled bare ground and facilities into bareground for analyses. We used ArcMap 9.1 to determine quantity and percentage of each vegetation type in annual home ranges and core areas of radiocollared deer. We used consecutive annual home ranges for individual deer to calculate the amount of overlap between consecutive home ranges. Data on overlap of consecutive annual home range were available for 54 deer over 8 years.

We analyzed data on size of home range, overlap of home range, size of core area, and type of vegetation using a mixed linear model (McLean et al. 1991) in SAS Proc Mixed (SAS Institute Inc., Cary, NC; Littell et al. 2006) with means estimated as least-square means. We used Akaike's Information Criterion to select the covariance structure that provided the best-fitting model for repeated measures analyses (Littell et al. 2006).

\section{RESULTS}

Of radiocollared female deer, $77 \%(n=95)$ were residents of DNWR, whereas $15 \%$ dispersed $(n=18)$ and $8 \%$ exhibited migratory patterns $(n=10)$. We delineated 175 annual home ranges for 68 resident deer through 11 years using 14,716 locations. We generated a mean of 3 annual home ranges (range 1-7) per deer for the 11 years of data. Mean size of annual home ranges and core areas for deer was $248 \mathrm{ha} \pm 14.8$ (SE; range $=24-1,411 \mathrm{ha})$ and $12 \mathrm{ha} \pm 0.98$ (SE; range 1-106 ha), respectively. Of annual home ranges,

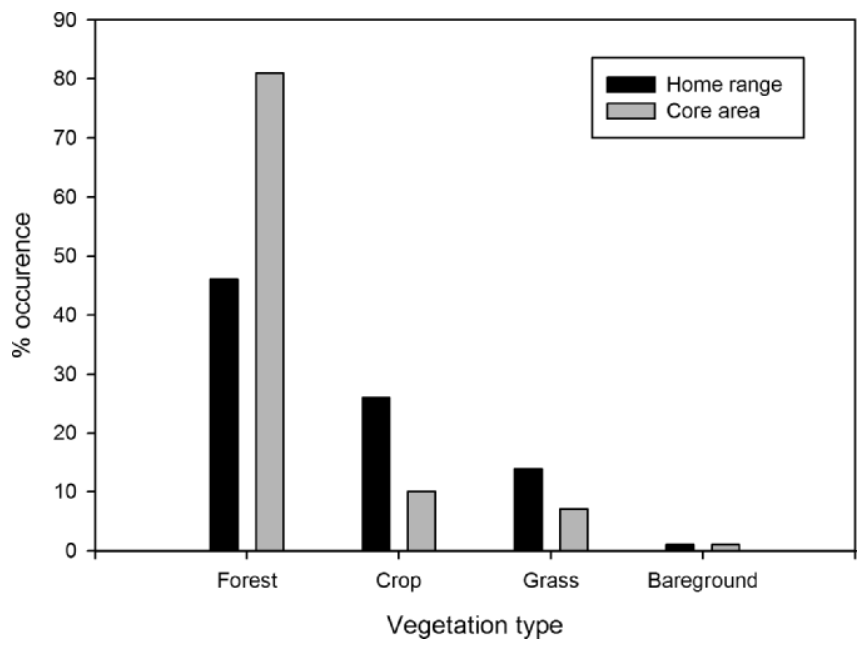

Figure 1. Average percentage of vegetation type in annual home ranges and core areas of resident female white-tailed deer on DeSoto National Wildlife Refuge in eastern Nebraska and western Iowa, USA, 1991-2004.

$75 \%$ were $<300$ ha, and $92 \%$ of core areas were $<20$ ha. Home ranges of yearling deer $(0=320$ ha $\pm 38 \mathrm{SE} ; n=27)$ were an average of nearly 100 ha larger than those of adult $\operatorname{deer}\left(0=235\right.$ ha $\left.\pm 16 \mathrm{SE} ; n=147 ; t_{84}=2.63, P=0.010\right)$, and core areas of yearlings $(0=17 \mathrm{ha} \pm 4 \mathrm{SE})$ were an average of 7 ha larger than adult core areas $(0=10$ ha \pm 1 $\mathrm{SE} ; t_{88}=2.58, P=0.012$ ).

Annual home ranges of deer on DNWR consisted of a mean of 108 ha of forest, 69 ha of crops, 36 ha of grass, and 5 ha of bareground over all years (Fig. 1). Further division of crops revealed that deer used a mean of 21 ha of corn, 21 ha of soybeans, 17 ha other, and 10 ha of wheat-clover mix within their annual home ranges (Fig. 2). Deer used a mean of 8 ha of forest, 1.5 ha of crops, 1 ha of grass, and 0.2 ha of bareground in their core areas over all years (Fig. 1). Deer used a mean of 1.2 ha of soybeans, 1 ha of other, 0.8 ha of corn, and 0.4 ha of a wheat-clover mix in their core areas (Fig 2).

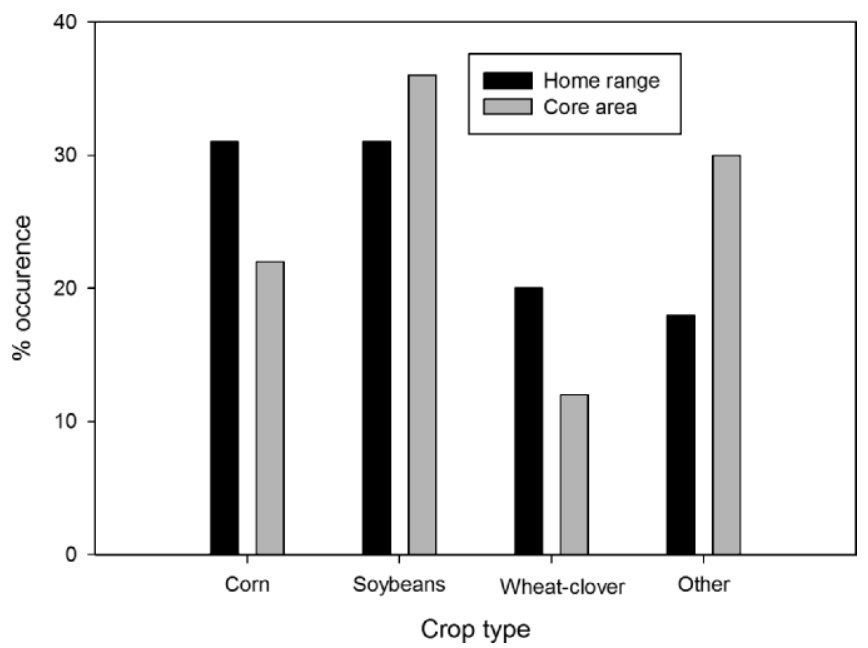

Figure 2. Average percentage of crop type in annual home ranges and core areas of resident female white-tailed deer on DeSoto National Wildlife Refuge in eastern Nebraska and western Iowa, USA, 1991-2004. 


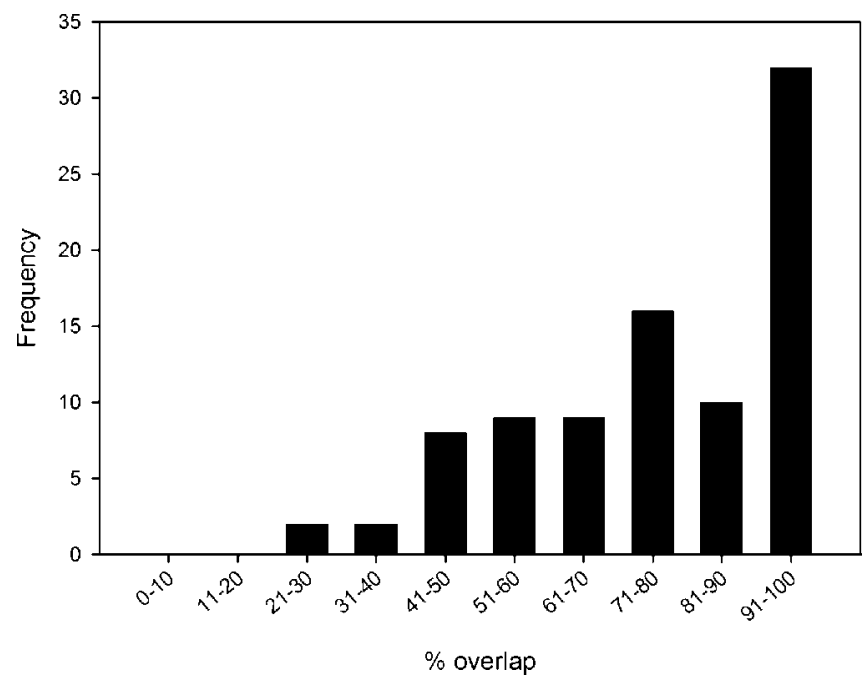

Figure 3. Frequency of occurrence for the amount of overlap in successive annual home ranges of resident female white-tailed deer on DeSoto National Wildlife Refuge in eastern Nebraska and western Iowa, USA, 1991-2004.

Fidelity to home range was high, with a mean of $77 \% \pm$ 2.17 (SE; range 24-100\%) overlap between consecutive annual home ranges for 54 individual deer across 8 years (Fig. 3). Of the deer for which we delineated consecutive annual home ranges, $59 \%$ had $>90 \%$ overlap with their previous year's annual home range. We observed no difference between yearlings and adults in amount of overlap between consecutive home ranges $\left(F_{1,86}=2.58, P\right.$ $=0.112$ ).

Availability of crops to deer on DNWR decreased an average of $4 \%$ (35 ha) per year (range $0-16 \%$ ), and overall availability of crops decreased by $44 \%$ (454 ha) between 1991 and $2004\left(R^{2}=0.97\right.$; Fig. 4). Although average size of home ranges fluctuated from year to year, it declined from about 400 ha to 200 ha over 11 years $\left(R^{2}=0.39\right)$. Although amount of crops in DNWR decreased, percentage of crops in the home ranges of deer increased from $21 \%$ in 1992 to $29 \%$ in $2004\left(R^{2}=0.57\right)$.

\section{DISCUSSION}

As the amount of crops on the landscape decreases, deer may gradually shift their home ranges to obtain preferred forages, but substantial increases in size of home range or home range abandonment for alternate areas is unlikely. Home ranges of resident female deer in our study were $<300$ ha and were comparable to those reported in research with analogous types of vegetation (range: $144-400$ ha; Dusek et al. 1988, Nixon et al. 1991). A core area is the area with the highest density of locations within a home range (Kernohan et al. 2001) and core areas of deer in our study area were predominately in forests that provided security and thermal cover. Only $25 \%$ of deer did not have crops in their core areas, indicating that deer typically used crops for feeding or seasonally when natural forage was limited. Furthermore, we observed a high level of overlap $(77 \%)$ of home ranges for deer over successive years, indicating a high fidelity to their

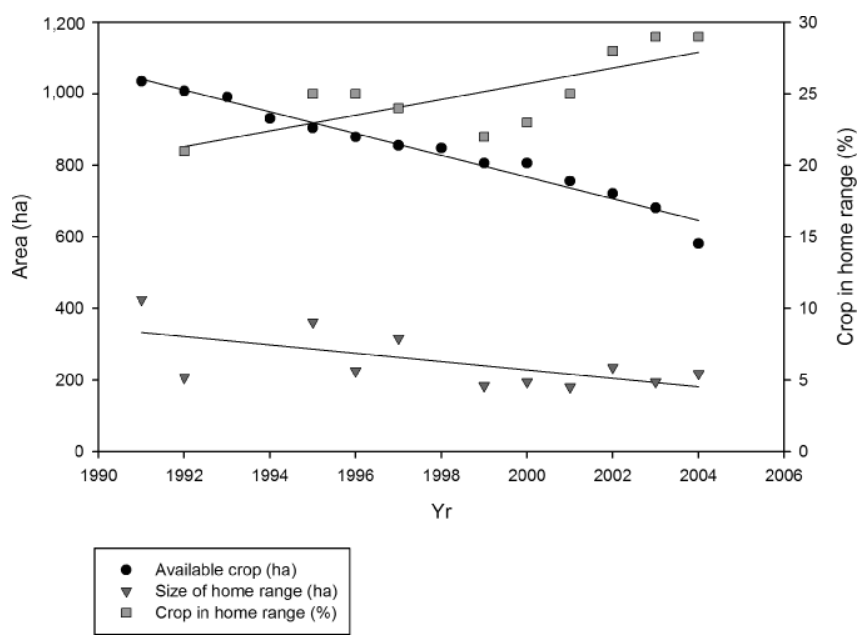

Figure 4. Trends of home range size, and availability and use of crops by resident female white-tailed deer on DeSoto National Wildlife Refuge in eastern Nebraska and western Iowa, USA, 1991-2004.

home ranges as previously reported for deer (Tierson et al. 1985, Nelson and Mech 1999, Lesage et al. 2000). Due to strong fidelity, successive home ranges were often dependent on previous home ranges but may have been altered by the availability of habitat types. McShea and Schwede (1993) observed that female deer in Virginia, USA, increased their home ranges to incorporate acorn-producing areas during autumn. In Nebraska, deer shifted their home ranges $174 \mathrm{~m}$ toward cornfields during the silking-tasseling stage and 157 $\mathrm{m}$ away from cornfields after harvest (VerCauteren and Hygnstrom 1998).

A reduction in size of home range and increase of crops within home ranges suggested a $44 \%$ reduction in crops at DNWR was not enough to alter use of the landscape by deer at current population densities. Differences in availability of crops, size of home ranges, and percent of crops in home ranges were minimal between successive years but long-term differences from 1991 to 2004 were noteworthy. Availability of crops on DNWR decreased by 44\% from 1991 to 2004 and a concomitant decrease in mean size of home range was also observed during this period. Although percentage of crops in home ranges increased from $21 \%$ to $29 \%$, percentage of crops in core areas remained the same throughout our study. Kilpatrick and Stober (2002) documented shifts in core areas of home ranges towards bait sites but deer did not leave their annual home ranges to include bait sites that were previously outside of their home range. Our deer did not abandon their home ranges to incorporate adjacent crops but gradually shifted home ranges over several years to access fields remaining in crop rotation. Similarly, Beier and McCullough (1990) reported that female deer did not change their use of areas in response to availability of forages.

The decrease in size of home ranges that we observed occurred with a gradual conversion of crops to native grasses on DNWR and a gradual increase in density of deer over 14 years. A reduction in size of home range could be due to increased social interactions limiting space use by deer. 
Variability in size of home range occurred with reduction in densities of deer; however, considerable habitat differences between a residential community and a forested peninsula were the likely cause of these differences observed in Henderson et al. (2000) and Kilpatrick et al. (2001), respectively. Home ranges of deer at DNWR included slightly more crops later in the study (i.e., 2004) but size of home ranges decreased, suggesting that regardless of the mechanisms controlling size of home range, deer on DNWR did not increase size of home range in response to loss of crops. Similarly, when fencing excluded deer from preferred feeding sites such as alfalfa fields, deer increased use of vegetation types other than alfalfa within their home ranges rather than expanding their home range to include unprotected alfalfa fields (Hygnstrom 1988).

The size of a deer's home range is likely dependent on many factors including habitat, food availability, geographic region, social interactions, and density of the population (Beier and McCullough 1990, McShea and Schwede 1993, Nelson and Mech 1999, Kilpatrick and Stober 2002). Henderson et al. (2000) reported an increase in size of home range following a $50 \%$ reduction in the density of deer in a residential community, whereas Kilpatrick et al. (2001) reported a $56 \%$ decrease in size of home range following an $82 \%$ (72 deer $/ \mathrm{km}^{2}$ remained) reduction in density of deer on a forested peninsula. Density of deer on DNWR increased from 19 deer $/ \mathrm{km}^{2}$ to $33 \mathrm{deer} / \mathrm{km}^{2}$ from 1991 to 2004 with a decrease in mean size of home ranges from 400 ha to 200 ha during the same time frame. Our study and Henderson et al. (2000) found an inverse relationship, whereas Kilpatrick et al. (2001) found a positive relationship, between size of home range and population density. Although we were unable to control for effects of density of deer on our results, the disparity from previous research on the relationship between size of home range and density of deer suggested that landscape complexity and productivity (e.g., amt of edge and habitats types; Ford 1983) may have greater influence on size of home range and use of crops than density of deer.

\section{MANAGEMENT IMPLICATIONS}

Results of our research provide valuable information about the size of home ranges and habitat use by deer in response to the changing landscape on DNWR that would mimic future land conversion for production of biofuels. Conversion of crops to native grasses on our study area is comparable to that of the CRP on private property and the recent trend to convert land to native vegetation or aquatic habitats for production of biofuels (Bies 2006, Tilman et al. 2006). Resource managers should understand that conversion of crops to native vegetation or aquatic habitat would likely result in considerable variation in their suitability and seasonal use by deer. Furthermore, after crops are converted, areas that contain crops may sustain greater levels of use by deer in the absence of deer control efforts. Shifts in core areas to consume preferred forages may increase seasonal contact rates between deer in different social groups and could, thus, increase the transmission rates of disease. Our results suggest that fidelity to home range may minimize movements of deer across a landscape following alteration of habitat, but further research is needed to understand the long-term and large-scale effects of habitat conversion on condition and use of space by deer in agro-forest landscapes across the Midwest that are targeted for production of biofuels.

\section{ACKNOWLEDGMENTS}

We were funded by the University of Nebraska-Lincoln Research Council, Institute of Agriculture and Natural Resources, and the Integrated Pest Management-Vertebrates Program; National Wildlife Research Center of the United States Department of Agriculture, Animal and Plant Health Inspection Service, Wildlife Services; United States Fish and Wildlife Service; Nebraska Game and Parks Commission; Safari Club International; Nebraska Bowhunters Association; Professional Bowhunters Association; Cabela's Incorporated; and the Berryman Institute for Wildlife Damage Management. We thank G. Gage, L. Klimek, M. Buske, B. Barry, M. Sheets, and several other personnel at DNWR for providing study sites, equipment, assistance, maintenance, lodging, and camaraderie necessary for the study. G. Clements, M. Clements, S. Korte, and J. Olnes assisted with data collection and analysis. Statistical support was provided by E. Blankenship.

\section{LITERATURE CITED}

Beier, P., and D. R. McCullough. 1990. Factors influencing white-tailed deer activity patterns and habitat use. Wildlife Monographs 109.

Bies, L. 2006. The biofuel explosion: is green energy good for wildlife? Wildlife Society Bulletin 34:1203-1205.

Dusek, G. L., R. J. Mackie, J. D. Herriges, Jr., and B. B. Compton. 1989. Population ecology of white-tailed deer along the lower Yellowstone River. Wildlife Monographs 104.

Dusek, G. L., A. K. Wood, and R. J. Mackie. 1988. Habitat use by whitetailed deer in prairie-agricultural habitat in Montana. Prairie Naturalist 20:135-142.

Ford, R. G. 1983. Home range in a patchy environment: optimal foraging predictions. American Zoologist 23:315-326.

Gilsdorf, J. M., K. C. VerCauteren, S. E. Hygnstrom, W. D. Walter, J. R. Boner, and G. M. Clements. 2008. An integrated vehicle-mounted telemetry system for VHF telemetry applications. Journal of Wildlife Management 72:1241-1246.

Henderson, D. W., R. J. Warren, J. A. Cromwell, and R. J. Hamilton. 2000. Responses of urban deer to a $50 \%$ reduction in local herd density. Wildlife Society Bulletin 28:902-910.

Hygnstrom, S. E. 1988. Animal damage control in Wisconsin. Dissertation, University of Wisconsin, Madison, USA.

Kernohan, B. J., R. A. Gitzen, and J. J. Millspaugh. 2001. Analysis of animal space use and movements. Pages 125-166 in J. J. Millspaugh and J. M. Marzluff, editors. Radiotracking and animal populations. Academic Press, San Diego, California, USA.

Kernohan, B. J., J. A. Jenks, D. E. Naugle, and J. J. Millspaugh. 1996. Estimating 24-h habitat use patterns of white-tailed deer from diurnal use. Journal of Environmental Management 48:299-303.

Kilpatrick, H. J., A. J. DeNicola, and M. R. Ellingwood. 1996. Comparison of standard and transmitter-equipped darts for capturing white-tailed deer. Wildlife Society Bulletin 24:306-310.

Kilpatrick, H. J., S. M. Spohr, and K. K. Lima. 2001. Effects of population reduction on home ranges of female white-tailed deer at high densities. Canadian Journal of Zoology 79:949-954.

Kilpatrick, H. J., and W. A. Stober. 2002. Effects of temporary bait sites on 
movements of suburban white-tailed deer. Wildlife Society Bulletin 30: 760-766.

Lesage, L., M. Crete, J. Huot, A. Dumont, and J. Ouellet. 2000. Seasonal home range size and philopatry in two northern white-tailed deer populations. Canadian Journal of Zoology 78:1930-1940.

Littell, R. C., G. A. Milliken, W. W. Stroup, R. D. Wolfinger, and O. Schabenberger. 2006. SAS for mixed models. SAS Institute, Cary, North Carolina, USA.

Lopez, R. R., P. M. Harveson, M. N. Peterson, N. J. Silvy, and P. A. Frank. 2005. Changes in ranges of Florida Key deer-does population density matter? Wildlife Society Bulletin 33:343-348.

McLean, R. A., W. L. Sanders, and W. W. Stroup. 1991. A unified approach to mixed linear models. The American Statistician 45:54-64.

McShea, W. J., and G. Schwede. 1993. Variable acorn crops: responses of white-tailed deer and other mast consumers. Journal of Mammalogy 74: 999-1006.

Nelson, M. E. 1993. Natal dispersal and gene flow in white-tailed deer in northeastern Minnesota. Journal of Mammalogy 74:316-322.

Nelson, M. E., and L. D. Mech. 1999. Twenty-year home-range dynamics of a white-tailed deer matriline. Canadian Journal of Zoology 77:11281135.

Nixon, C. M., L. P. Hansen, P. A. Brewer, and J. E. Chelsvig. 1991. Ecology of white-tailed deer in an intensively farmed region of Illinois. Wildlife Monographs 118.

Rodgers, A. R., and A. P. Carr. 1998. HRE: the home range extension for ArcView $^{\mathrm{TM}}$ : user's manual. Ontario Ministry of Natural Resources, Centre for Northern Forest Ecosystem Research, Thunder Bay, Canada.
Smith, J. R., R. A. Sweitzer, and W. F. Jensen. 2007. Diets, movements, and consequences of providing wildlife food plots for white-tailed deer in central North Dakota. Journal of Wildlife Management 71:2719-2726.

Tierson, W. C., G. F. Mattfeld, R. W. Sage, and D. F. Behrend. 1985. Seasonal movements and home ranges of white-tailed deer in the Adirondacks. Journal of Wildlife Management 49:760-769.

Tilman, D., J. Hill, and C. Lehman. 2006. Carbon-negative biofuels from low-input high-diversity grassland biomass. Science 314:1598-1600.

U.S. Fish and Wildlife Service. 2001. Desoto National Wildlife Refuge final comprehensive conservation plan and environmental assessment. U.S. Department of the Interior, Fort Snelling, Minnesota, USA.

VerCauteren, K. C. 1998. Dispersal, home range fidelity, and vulnerability of white-tailed deer in the Missouri River valley. Dissertation, University of Nebraska, Lincoln, USA.

VerCauteren, K. C., J. Beringer, and S. E. Hygnstrom. 1999. Use of netted cage traps for capturing white-tailed deer. Pages 155-164 in G. Proulx, editor. Mammal trapping. Alpha Wildlife Research \& Management, Sherwood Park, Alberta, Canada.

VerCauteren, K. C., and S. E. Hygnstrom. 1998. Effects of agricultural activities and hunting on home ranges of female white-tailed deer. Journal of Wildlife Management 62:280-285.

World Resources Institute. 2008. WRI EarthTrends monthly update page. $<$ http://earthtrends.org/updates/node/180>. Accessed 17 Sep 2008.

Worton, B. J. 1995. Using Monte Carlo simulation to evaluate kernel-based home range estimators. Journal of Wildlife Management 59:794-800.

Associate Editor: Euler. 